\author{
(online) $=$ ISSN $2285-3642$ \\ ISSN-L = $2285-3642$ \\ Journal of Economic Development, Environment and People \\ Volume 10, Issue 4, 2021 \\ URL: http://jedep.spiruharet.ro \\ e-mail: office jedep@spiruharet.ro
}

\title{
How political and social attitude could help to fully adopt the circular economy concepts for national benefit? A comparative study
}

\author{
Milena Ilić P. ${ }^{11}$, Marko Ranković ${ }^{1}$, Milutin Dobrilović ${ }^{3,}$ Dušan Stojaković ${ }^{4}$, Rocsana Bucea-Manea- \\ Toniş ${ }^{5}$ and Larisa Mihoreanu. \\ 1 University Business Academy, Novi Sad; Faculty of Contemporary Arts Belgrade, Information Technology \\ School ITS, Serbia \\ 2 University Union Nikola Tesla, Faculty of Information Technology and Engineering, Serbia \\ ${ }^{3}$ University of Belgrade, Faculty of Economics; \\ ${ }^{4}$ University Business Academy, Faculty of Contemporary Arts Belgrade, Serbia; \\ ${ }^{5}$ National University of Physical Education and Sport, Romania; \\ ${ }^{6}$ Bucharest University of Economic Studies, Faculty of Administration and Public Management, Romania;
}

\begin{abstract}
This comparative study shows how concepts like circular economy, innovation and competitiveness are understood, accepted and implemented in Romania and Serbia, countries with similar preoccupations for the European Union's recommendations and destiny.

It is shown that the similar results obtained outline the lack of continuity in applying the resilient strategy for general development and the strategic role of investments as a pillar of modernisation. Building a resilient and modern society requires fundamental and complex changes in the political decision-makers attitude and people's civic behaviour, linked to the circular economy principles, the need for substantial investments in top innovative research, high-tech products, and adequate public policies of general interest.
\end{abstract}

Keywords: circular economy, competitiveness, investments and patents governance, resilience, public policy, change, attitude and behaviour, Romania, Serbia.

JEL Codes: 030, Q01, Q55, Q58

How to cite : llic, M., Ranković, M., Dobrilović, M., Stojaković, D., Bucea-Manea-Ṭoniş, R., \& Mihoreanu, L. (2021). HOW POLITICAL and SOCIAL ATTITUDE COULD HELP to FULLY ADOPT THE CIRCULAR ECONOMY CONCEPTS FOR NATIONAL BENEFIT? A COMPARATIVE STUDY. Journal of Economic Development, Environment and People, 10(4), 6675. doi:http://dx.doi.org/10.26458/jedep.v10i4.713

1+ Corresponding author. Tel.: +381605522581

E-mail address: milena.ilic@its.edu.rs 


\section{Introduction}

This research offers a better understanding of how Serbia and Romania have understood to adopt the circular economy concepts as principles of societal resilience and individuals' health. The authors comparatively analyse those countries: one - a member of the European Union since 2007 and the other one - a candidate state to the EU and make few recommendations for the future actions.

The research departs from the last years' Global Competitiveness Reports [1] [2], glancing at the $11^{\text {th }}$ and $12^{\text {th }}$ pillars outlining the Business Dynamism and the Innovation Capability. It is kept in mind that the analysis should keep going with the European Union/European Commission indicators to fully understand how the transition towards a true circular economy can be fully achieved.

\section{Analysis of Romanian and Serbian fourth CE indicator}

The authors' decision to study one of the E.C. Indicators on Competitiveness and Innovation argues with the results obtained by Romania and Serbia, as discussed below. Limits are found since the very beginning - poor comparable data is poor that limit considerably the research of those countries' investments and patents. However, we hope that the meaningful analyses and the qualitative research compensate for such a lack.

\subsection{The Case Study of Romania}

The genuine concern of UE regarding the implementation of the circular economy aims to reduce the ecological footprint and recreate the nature//society harmony for anyone, according to the one health concept. Currently, Romania has an ecological footprint of 2.9 GHA per capita and its bio-capacity value is around 2.4 GHA per capita. To protect the environment, this has to increase by at least $0.5 \mathrm{GHA}$. To reach such a goal, considerable effort, energy, and time are needed. A reasonable way to touch the targets is using new and safe technologies for both nature and society, opening new and profitable investments in both innovation and high-tech products, creating new models of living and working, and getting the fundamental changes to building a responsible attitude and proactive behaviour in implementing the agile waste management [3].

The measures, directed to increase the economic indices and reduce the ecological footprint by 0.5 , help build a resilient society. Romania's continuous efforts to reduce its ecological footprint date from 19751990 and reached only 4 GHA per capita. As figures are not at all satisfactory, the process must multiply the options and adopt punctual policies to generalize the agile management implementation, apply innovation and social education to transform the attitude for work, living style, society and nature and give to it deep cultural dimensions.

The bio-capacity indicators show the annual dynamics of the ecosystem management consequences, the ugly and the good of the agricultural policies, practices, and their consequences against the population size, structure, and health status. Therefore, creating a favourable framework is more than necessary to improve ecosystems. The ecological footprint also varies according to the consumption patterns, the efficiency of production, management, and treatment of garbage; therefore, environmentally friendly measures are highly required [4]. The "One Health" concept implementation has officially recognized in 2019 in Romania. It calls for specialists' practical cooperation to find the best solutions for a 


\author{
(online) $=$ ISSN $2285-3642$ \\ ISSN-L $=2285-3642$ \\ Journal of Economic Development, Environment and People \\ Volume 10, Issue 4, 2021 \\ URL: http://jedep.spiruharet.ro \\ e-mail: office jedep@spiruharet.ro
}

safer and more comfortable future within the dynamic context of biodiversity. Prevention and conservation can't be attained without investments in applied innovation in all fields. The critical problem is that $40 \%$ of innovative products fail adoption causing losses of resources for research, design, development, and product promotion [5]. Even though Romania enjoys a good start in IT development, many sectors of activity do not benefit from its application: the fees' collection, the traffic smart solutions, the online health and education as modern tools of teleworking. The young entrepreneurs are open to finding out what alternative tools to stop innovation implementation fail and adverse environmental impact happens. It is still ignored that XR technology use, proved as highly effective in education, logistics, marketing, industrial testing, is still reduced.

The main factors found as causing innovation failure are: expensive technologies, lack of understanding the new added value of innovation, $\$$ lack of small budgets dedicated by managers to use the open-source technologies, XR and communication through social media, and collaboration B2B (business to business) cooperation, B2C (business to customer), B2E (business to education), B2G (business to Government) in a virtual network business environment [6]. The fact that the scientific research activity is developed through a separate minister too far from the establishments in real need of innovative products is another barrier that stops the development of an innovative activity, technological transfer, application of inventions/innovations in public/private partnership with the economic environment, better use of the scientific results, through a fair absorption and dissemination. There are quite a few establishments developed within ministers, corporations or universities that push the harmonization of policies with reality, facilitate innovation dissemination through resilient logistics and infrastructures: business incubator centres, $\mathbf{Q}$ technology transfer centres, $\mathbf{\uparrow}$ technology information centres, $\boldsymbol{\uparrow}$ industry liaison offices,

science and technology parks, clusters, and digital hubs. The rupture between science, education, and business market is still obvious and collaboration between entrepreneurs, academics, scientists and local authorities' representatives is still hesitant. Business centres, chambers of commerce, businesses, and other state holders have fostered innovative digital hubs: Romanian Automobile Manufacturers Association clusters or the Wallachia Hub Consortium. They facilitate the development of financial solutions, crosssectoral innovative internationalisation and specialisation, and the creation of a regional brand. Clusters come from different areas of activity such as: renewable energy, energy efficiency, $\$$ bio-economy Centre for Renewable Energy on the Black Sea and the Danube; mobile cluster - Danube Furniture Cluster; clusters in space technologies and applications; engineering hubs; clusters in the field of organic agriculture - Bio Concept Valea Prahovei; centres sustaining the entrepreneurial environment, providing services and assistance, economic missions, and integrated export services for SMEs - USH Pro Business. 
The rapid process of digitalisation and the use of IoT brought to the market new learning infrastructure for collaboration with companies aiming to accelerate the generation of innovative ideas to increase future profits, according to the 70/20/10 rule for business development: $70 \%$ of the future expected profit comes from $10 \%$ of the reallocated profit. The hubs demonstrate their force in the market, as the perfect collaborative environment gathering universities, research institutes, IT\&C companies, regional public authorities, non-governmental organisations and are worth the initial investment effort. Thus, the Innovation-friendly environment and Sales impacts represent essential items of innovation and explain the reasonable bio-capacity deficit. Romania has closer values to EU performance if talking about broadband penetration (with the $5 \mathrm{G}$ technologies already implemented) and medium and high-tech product exports. As a future target, Romania should invest in Human resources and Lifelong learning for a more positive effect on innovation and a resilient future of society [7].

\subsection{The Case Study of the Republic of Serbia}

Serbia's priorities regarding its accession to the European Union in the forthcoming years impose a necessity that both Serbian legislation and recommendations for the circular economy (first of all those related to material resource efficiency and how raw materials are supplied) should be implemented. These fields are highly multidisciplinary and come with lots of responsibilities to be assigned to the central authorities: Ministry of Environmental Protection, Ministry of the Economy, Department of the Circular Economy of the Chamber of Commerce, and Serbian Environmental Protection Agency, as key institutions of the circular economy. Ecology protection is a significant domain of action for the Republic of Serbia in its strategy to achieve full membership to the EU. The management of the countryside, air, and water in compliance with the applicable international standards increasing the level of the nation's awareness of and education on the circular economy topic concerning all the directions of the development of the country shall be the backbone supportive of the approach systematically dealing with the problem subject matter. Providing more diverse "green activities" will increase the attractiveness of the country for new foreign investors. Processes like energy efficiency, recycling, renewable energy, rural tourism, and organic farming would enormously benefit from circular economy implementation.

The essential data regarding ecology protection shows that Serbia currently has an ecological footprint of 2.8 GHA per capita and the value of bio-capacity around 1.3 GHA per capita. Therefore, Serbia needs to increase its bio-capacity by at least $1.5 \mathrm{GHA}$ [3].

The UNDP initiated one of the essential projects intended for the circular economy in Serbia. "The Platform of the Circular Economy for Sustainable Development in Serbia", implemented in 2018 got together as partners with the Government, non-governmental sector, academic institutions, and business entities, etc. The project serves the UNDP to modify the linear approach to production and consumption channelling the approach towards the circular economy in disposable plastics, textiles, surplus food, and furniture at the same time. The platform focuses on identifying and eliminating any administrative and legal hurdles. Companies are also faced with their wish to run a business on a circular basis. Efforts are made to promote good practices. The activity timeline, the goals, and the desired outcomes are determined in the project. It also encompasses the finance field, namely the mechanisms used in finance, simultaneously making a framework the circular economy needs. Furthermore, creative industries beneficial for channelling the circular culture and the circular economy postulate closer to the youth are needed. The project's primary goal is to provide support for the sustainable development of the Republic of Serbia [8]. 


\author{
(online) $=$ ISSN $2285-3642$ \\ ISSN-L $=2285-3642$ \\ Journal of Economic Development, Environment and People \\ Volume 10, Issue 4, 2021 \\ URL: http://jedep.spiruharet.ro \\ e-mail: office jedep@spiruharet.ro
}

The OSCE agrees that the Republic of Serbia's new legislative framework which implies the measures supporting the waste management hierarchy principle, mainly so the measures supporting waste generation prevention, is the first step to be made by the country towards reaching the circular economy [9].

The Serbian circular economy concept is in the developmental phase. The central part refers to the manufacturing sector. The concept as emerged a few years ago in the European Union has already pursued the European Union's full membership status. Several small and medium-sized enterprises have been operating in the commercial sphere and industry under the auspices of the circular economy. A Centre for the Circular Economic has been established at the Chamber of Commerce at the institutional level. The new 2019-2025 Waste Management Strategy, envisaged in compliance with the National Waste Management Plan, is already in force. Furthermore, the Strategy for the Development of the Energy Sector by the Year 2025 is supposed to guarantee that, by the defined year, an efficient energy market will have been developed, renewable energy sources will have increasingly been used, and ecological promotion in the energy activity field will have been made [10]. The Sustainable Urban Development Strategy for the Republic of Serbia by 2030 identifies priority activities intended to implement the circular economy principles more efficiently, as follows: the prevention of the uncontrolled expansion of construction in natural habitats; the application of closed circular cilia in construction land management; the development of a compact city concept concerning an urban expansion not following the plan [12].

Currently, Serbia started designing an environmental management system, based on the support of 15 companies, regularly reporting on sustainable development in compliance with internationally recognised standards [11]. It is believed that the circular economy concept is potentially able to employ more than 30,000 people through direct implementation activities. This will enable better standards for society and will help preserve and protect all the natural resources. Competent authorities are expected to drive the transformation process by proactive participation and support both the implementation of the circular economy and its national resilient development. Few structural reforms already frame the economic situation as a great opportunity for the circular economy to develop [12].

The renewable resources (primarily solar and wind parks) are part of the energetic potential of Serbia, and tangible support for the energy sources. However, the biggest hurdle to investing more in renewable is the lack of start-up capital, preventing investors from starting a business. Additionally, this identified issue is accompanied by the mentioned hurdle in pending land ownership administration and no development plan for some areas.

Professionals have reserves in thinking of a linear transition to the circular and the complete contribution that Parliament and Government could give to the circular economy concept. Questions arise with regard to the academic and educational establishments' contribution next to the civil population implication too. 
Essential solutions have to be considered in this respect. Therefore, the roles played by those participants, their attitudes linked to the ecological issues, the role of the non-governmental sector, academic institutions, and non-governmental bodies is also of great importance in designing educational, financial, and regulatory frameworks for the circular economy and need quite a definition [13].

The innovations generated through knowledge management make significant contributions to companies' business by making their business processes more efficient and enhancing the quality and productivity of those companies [16]. Nowadays, companies carry out their business operations under immense pressure, simultaneously competing with a very tough market. To better manage the novel labour conditions, companies are pressured into constantly seeking to keep efficiency in doing business [12]. In addition, they have to cope with how to introduce to the market their creative innovations, novel products made, and rendered services. Furthermore, presenting and implementing innovations effectively makes companies recognisable and memorable for the customers, increasing their competitiveness and enabling the strengthening of their organisational performances [15].

\subsection{Romania and Serbia - a comparison}

According to the GCR of the World Economic Forum (2019), Romania ranked $51^{\text {st }}$ of the 141 countries with the recorded value of the IGC 64.4, moving one place up since the 2018th report when it was ranked at $52^{\text {nd }}$ place with an IGC score of 63.2. At the same time, Serbia ranked $72^{\text {nd }}$ on the ranking list with the recorded value of the IGC 60.9, dropping seven places down since the 2018 report when Serbia was ranked at $65^{\text {th }}$ place with recorded the same value score of IGC 60.9 [1]. Regarding the ability to innovate business activities in Romania ( $12^{\text {th }}$ pillar: Innovation capability), Romania ranked $55^{\text {th }}$ of the 141 countries with a 42.3 point score [2]. The previous years' reports show that, in comparison with the year 2018, Romania ranked two positions lower $\left(57^{\text {th }}\right)$ on the same ranking list, maintaining a 39.6 point score for innovation [1]. For the same pillar, Serbia ranked $59^{\text {th }}$ of the 141 countries with a 40.2 points score, according to the source [2]. The report of the previous year shows that Serbia ranked three positions lower $\left(56^{\text {th }}\right)$, with a 39.7 point score for innovation capability. Regarding the business activity dynamism, Romania has $72^{\text {nd }}$ position $\left(11^{\text {th }}\right.$ pillar: Business dynamism) in 2019 with 59.7 points (out of 100), which compared to 2018, shows that Romania ranking has improved by eight places $\left(64^{\text {th }}\right.$ place with 60.1 point scale in 2018) do to the insufficient business dynamism in general, but also its business dynamism score dropped by 0.3 points. At the same time, Serbia took $54^{\text {th }}$ place with a 63.1 point score (out of 100 ) and gained an additional 2.2 points in business activity dynamism in 2019 as compared with 2018 as Serbian ranking has improved by five places (in 2018, Serbia ranked at $59^{\text {th }}$ place with 60.9 point score) due to the insufficient business dynamism in general. Table 1 compares Romania and Serbia in their Global Competitiveness ranks and scores for chosen pillars.

Table 1. Comparison between Romania and Serbia is Global Competitiveness ranks and scores for chosen pillars for Romania and Serbia, Calculation based on [2].

\begin{tabular}{rcccc}
\hline & Romania 2019 & Romania 2018 & Serbia 2019 & Serbia 2018 \\
\hline GCl rank (1-141) & 51 & 52 & 65 \\
\hline GCl score (0-100) & 64.4 & 63.2 & 60.9 & 60.9 \\
\hline $\mathbf{1 1}^{\text {th }}$ pillar rank Business dynamism (1-141) & 72 & 64 & 54 & 69 \\
\hline $\mathbf{1 1}^{\text {th }}$ pillar score Business dynamism (0-100) & 59.7 & 60.1 & 53.1 & 59 \\
\hline $\mathbf{1 2}^{\text {th }}$ pillar rank Innovation capability (1-141) & 55 & 39.9 & 56 \\
\hline $\mathbf{1 2}^{\text {th }}$ pillar score innovation capability (0-100) & 42.3 & 39.6 & 39.7 \\
\hline
\end{tabular}




\author{
(online) $=$ ISSN $2285-3642$ \\ ISSN-L $=2285-3642$ \\ Journal of Economic Development, Environment and People \\ Volume 10, Issue 4, 2021 \\ URL: http://jedep.spiruharet.ro \\ e-mail: office jedep@spiruharet.ro
}

The business dynamism element administrative requirements within the GCR are measured based on four components: Cost of starting a business; Time to start a business; Insolvency recovery rate, and Insolvency regulatory framework. A comparison of data for Romania and Serbia is shown in the following table (Table 2).

Table 2. Comparison of Business Dynamism element Administrative requirements for Romania and Serbia, Calculation based on [2]

\begin{tabular}{|c|c|c|c|c|}
\hline \multirow{2}{*}{$\begin{array}{r}\text { Country } \\
\text { Components of Administrative } \\
\text { requirements }\end{array}$} & \multicolumn{2}{|c|}{ Romania } & \multicolumn{2}{|c|}{ Serbia } \\
\hline & Score $(1-100)$ & Rank(out of 141) & Score $(1-100)$ & Rank (out of 141) \\
\hline Cost of starting a business & 99,8 & 9 & 98,9 & 45 \\
\hline Time to start a business & 65,3 & 123 & 95,0 & 27 \\
\hline Insolvency recovery rate & 38,5 & 75 & 37,1 & 78 \\
\hline Insolvency regulatory framework & 81,3 & 17 & 84,4 & 14 \\
\hline
\end{tabular}

As shown in Table 2, Romania is ahead of Serbia in most Administrative requirements, such as the Cost of starting a business, Insolvency recovery rate. However, Serbia is ahead of Romania regarding the time to start a business and Insolvency regulatory framework.

\title{
3. Discussion
}

Regarding the analysis of the importance of investments in innovation, in the increasing number of patents for EU, the regression analysis showed that innovation, as part of the circular economy, is supported mainly, but not exclusively by investments. The individuals' level of education, knowledge, and culture impact proportionally innovation, adding value to creating new jobs and opportunities in CE.

In the EU, Germany is the most innovative country regarding eco-innovation when analysing the recycling and secondary raw materials patents, although in the last years had a decreasing evolution, followed by France, Poland, Spain, Italy, and the UK (Figure 1). 


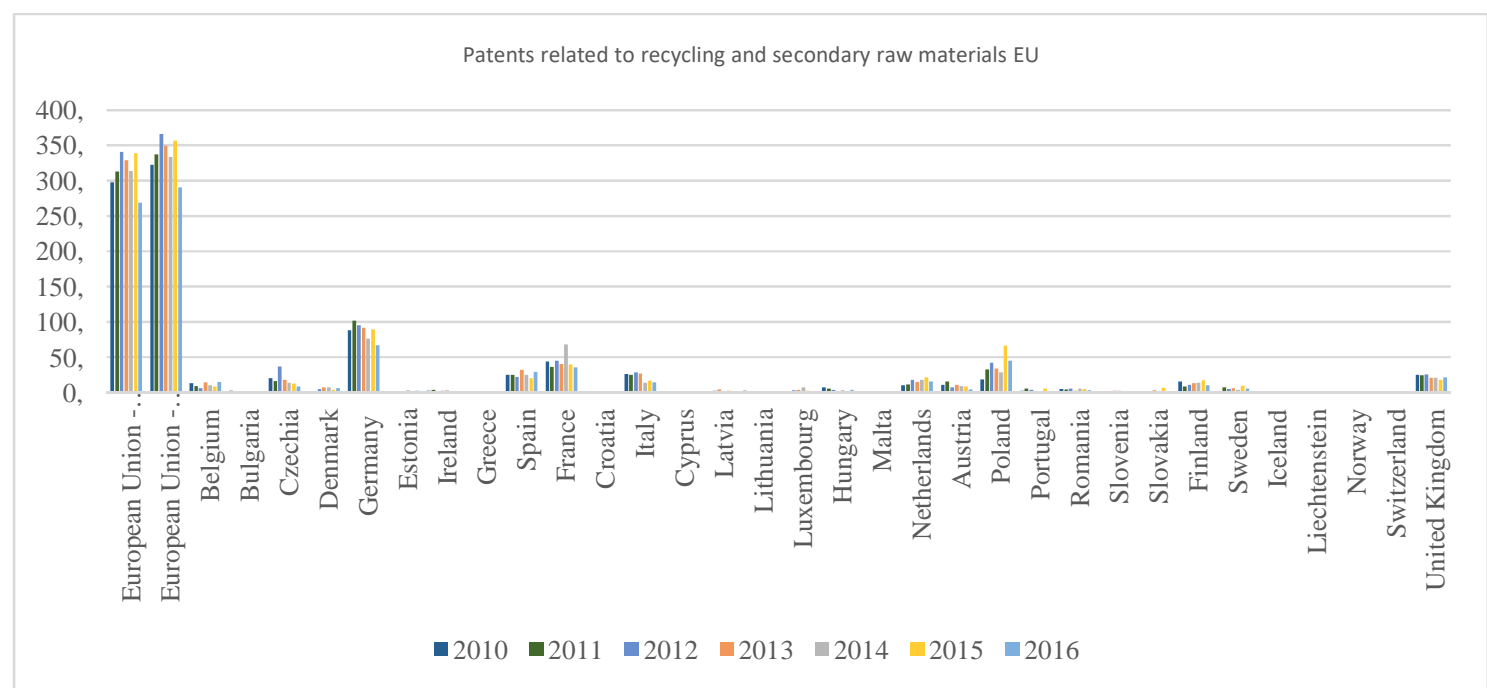

Figure 1. Patterns regarding recycling and secondary raw materials in the E.U. Calculation based on [16].

Eco-innovation creates many jobs involving a new working force and brings added value within a circular and sustainable economy. Countries with high investments like Germany, France, Italy, and the UK have more patents, showing a strong correlation between private investments in CE and patents in CE, emphasizing the vital role of investments in innovation processes. Other patterns are visible: Poland is very motivated and innovative with fewer investments than countries like Spain who beneficiate from high investments, and files only a few patents (Figure 2).

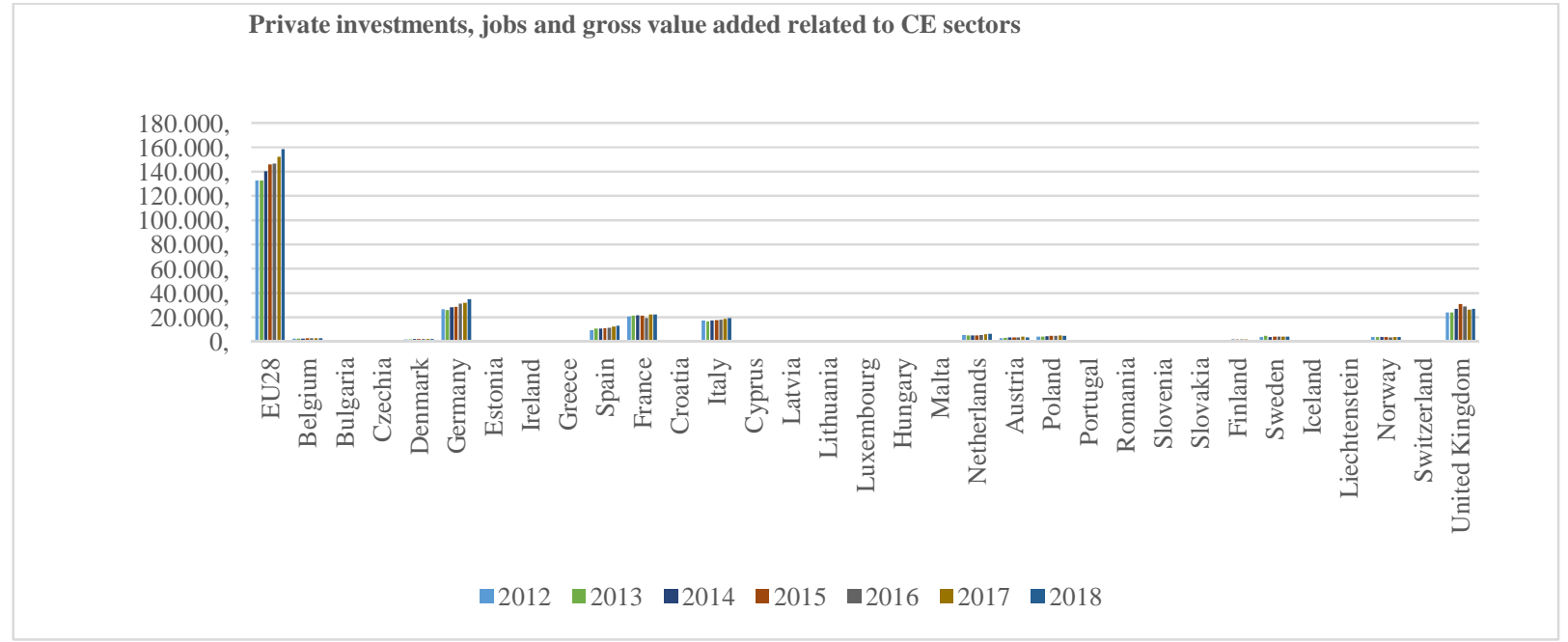

Figure 2. Private investments with a positive influence in the circular economy, calculation based on [16].

These results suggest that other factors like culture, management, IT readiness, collaboration platforms influence innovation represented as a model of innovations [18]. 


\author{
(online) $=$ ISSN $2285-3642$ \\ ISSN-L $=2285-3642$ \\ Journal of Economic Development, Environment and People \\ Volume 10, Issue 4, 2021 \\ URL: http://jedep.spiruharet.ro \\ e-mail: office jedep@spiruharet.ro
}

\title{
4. Conclusion
}

The information presented illustrates the Serbian and Romanian efforts to build a circular economy. An analysis and recommendations for future solutions are done on the good and bad aspects of how waste and energy are handled now and treated. Sharing economy projects and collaboration among digital hubs in Romania and Serbia are great ways to help build two healthy European societies, moving towards digitalization with such initiatives as collaborating in digital clusters and hubs. a recommended solution would be woven into all educational programs until it becomes commonplace knowledge for citizens, and this knowledge influences their mindset so that they adopt sustainable environmental habits. After quantifying and characterizing the information, the study yields greater insight into the current innovation and competitiveness scenario for the nations of the world shown in the study. Due to this shortcoming, specific data on Serbia was not readily available. This enabled analyses that could be performed based on the data that was available and qualitative methods. The years 2018 and 2019, selected as base years within the explanation periods are relevant for both countries as a pre-Covid-19 period. As a future direction of research, the research will go on with a further comparison of both countries' innovation and competitiveness during the Covid-19 pandemic.

\section{References}

1. Schwab, K. (2018). The Global Competitiveness Report. Geneva: World Economic Forum. Retrieved 12 30, 2020, from http://www3.weforum.org/docs/GCR2018/05FullReport/TheGlobalCompetitivenessReport2018.pdf.

2. Schwab, K. (2019). The Global Competitiveness Report 2019. Geneva: World Economic Forum. Retrieved 12 19, 2020 , from http://www3.weforum.org/docs/WEF_TheGlobalCompetitivenessReport2019.pdf.

3. Global Footprint Network. (2021, 01 15). Advancing the Science of Sustainability. Retrieved from https://data.footprintnetwork.org/?_ga=2.213842196.1854544587.1614252856-1733123981.1614252856\#/.

4. One Health. Retrieved from www.onehealth.ro. (accessed 10.07.2021.)

5. Ceniga, P \& Sukalova, V. (2020). Sustainable Business Development in the Context of Logistics in the Globalization Process Sustainable Business Development in the Context of Logistics in the Globalization Process. SHS Web of Conferences 74, 04003 Globalisation and its Socio-Economic Consequences. doi: https://doi.org/10.1051/shsconf/20207404.

6. El-Kassar, A. N \& Singh, S. K. (2019). Green innovation and organisational performance: The influence of big data and the moderating role of management commitment and HR practices. Technological forecasting and social change, 144, 483-498. doi:10.1016/j.techfore.2017.12.016.

7. European innovation scoreboard https://ec.europa.eu/growth/industry/policy/innovation/scoreboards_en (accessed 10.06.2021). 
8. UNPD Serbia. (2020, $12 \quad$ 21). UNDP Serbia. Retrieved from https://www.rs.undp.org/content/serbia/sr/home/presscenter/articles/2019/circular-economy-for-sustainabledevelopment-in-serbia.html.

9. OSCE. (2019). Cirkularna ekonomija kao šansa za razvoj Srbije. Retrieved 12.21.2020, from https://www.osce.org/sr/serbia/292311?download=true.

10. Eionet Report. (2019). Serbia, Resource efficiency and circular economy in Europe - even more from less, An overview of policies, approaches and targets of Serbia.

11.Đurić, S., Stošić Mihajlović, Lj \& Trajković, S. 2017). Circular economy and create new values - recycling, renewable energy, ecology. Journal of Process Management - New Technologies, International, 5(3), 50-68.

12. Mihoreanu, Larisa. 2020. The Medical Clinic of Proximity: Business Controversies and Medical Challenges in Thrassou, A., Vrontis, D., Weber, Y., Shams, S.M.R., Tsoukatos, E. (Eds.). 2020. The Changing Role of SMEs in Global Business Vol. I: Paradigms of Opportunities and Challenges. pp: 43-64. Palgrave Macmillan.

13. Ilić, M., Popović Šević, N., Bašić, J \& Ranković, M. (2020). Environmental Protection and the Circular Economy; A New Economic System for Society and a Business Strategy - The Case Study of the Republic of Serbia. $20^{\text {th }}$ International Multidisciplinary Scientific GeoConference SGEM 2020. Albena. doi:10.5593/sgem2020/5.2/s21.028.

14. Donate, M. J \& Sánchez de Pablo, J.D. (2015). The role of knowledge-oriented leadership in knowledge management practices and innovation. Journal of Business Research, 68(2), 360-370. doi: https://doi.org/10.1016/j.jbusres.2014.06.022.

15. Eurostat. (2021, 10 02). Patents related to recycling and secondary raw materials (cei_cie020). Retrieved from https://ec.europa.eu/eurostat/cache/metadata/en/cei_cie020_esmsip2.htm.

16. Ferreira, J., Fernandes, C. \& Ratten, V. (2017). Entrepreneurship, innovation and competitiveness: what is the connection? International Journal of Business and Globalisation, 18(1), 73-95.

17. Eurostat. (2021, 10 02). Private investments, jobs and gross value added related to circular economy sectors (cei_cie010). Retrieved from https://ec.europa.eu/eurostat/databrowser/view/cei_cie010/default/table?lang=en.

18. Bucea-Manea-Țoniș, R.c \& Bucea-Manea-Țoniș, R. (2019). SMEs innovation in a network environment, a case study in Romania. International Journal of Management and Production, 10(3). doi:dx.doi.org/10.14807/ijmp.v10i3.878. 